\title{
Paradigm Shifts: Climate Change and Water Allocation
}

\author{
Anteneh Belayneh* \\ Quebec Representative, Italy
}

Submission: August 13, 2017; Published: October 13, 2017

*Corresponding author: Anteneh Belayneh, Quebec Representative, Gatineau, Italy, Email: antenehbelayneh@cmail.carleton.ca

\section{Opinion}

Climate change is not an impending event, it has already arrived. Its extent is unclear, but notions of an impending or present mass extinction abound. Global warming is tempered by our seas, where more than a third of the planet's carbon is stored. These oceans, enormous sinks of carbon and home to vast and diverse life forms, will transform from a preserver of climatic balance to a destroyer of it. Barring a radical reduction of emissions, we will see at least four feet of sea-level rise and possibly ten by the end of the century.

Climate change appears to be the most pressing collective action problem of modern times. Global coordination initiatives - from Kyoto to Paris -have not, to date, resulted in an appreciable reduction of emissions or in any discernable shift, globally, our economic system. Fundamentally, human perceptions of water, fish and nature generally has been through the lens of a resource. This paradigm of viewing, for example, water as instrumental for human development and advancement persists and is a barrier to any lasting transition in human relationships with nature (resources).

The collective action problem is rooted in human conceptions of nature. The global collective action problem on climate change is mirrored by various collective action problems between national and sub-national governments. These collective action problems center around the need for economic development and the need to conserve environmental integrity. Water allocation is a striking example of this bifurcation of responsibilities. On the one hand, there are national governments responsible for the environmental objectives surrounding water, including the protection of inland fisheries. On the other hand, sub-national governments are responsible for allocating water for resource development projects.

The existing paradigm of water as instrumental to development needs to be reconciled with the unprecedented changes climate change is bringing about. This paradigm begets cost benefit analysis' on whether to conserve or to develop. These utilitarian questions need to be abandoned as a 6th mass extinction is already underway and these questions may presently become moot.

While humans struggle collectively on how to address climate and reduce GHG emissions, the existing paradigm of resource development has not distributed its gains equally. Water access and water allocation are not so much supply problems as they are distributive problems. While two-thirds of the world's population is expected to face water scarcity by 2025 , this scarcity is in contrast with water abundant countries such as Canada. Global water distribution issues are mirrored on a national and regional scale, where even Canada's prairies and indigenous communities are vulnerable to water shortages.

So, what is the link? Why is water allocation in water rich Canada being discussed in concert with the collective action problem that is climate change? Water has historically been allocated along our development imperatives. Traditionally water has been allocated to irrigation or power development programs. These allocations were critical to the emergence of critical industries and communities throughout North America. Environmental protection, conservation and the preservation of aquatic habitats was not on the public policy agenda when water allocations were initially distributed.

The emergence of the environment as a user of water pits it in direct competition with historically dominant water users such as agriculture or power generation. The collective paradigm shift required in our conception of nature to address climate is also required to reallocate water. This development oriented paradigm, while essential to the growth of North America, is a barrier to distributing water among different users and, particularly the environment. Unless this shift occurs to address the collective action problem between national and subnational governments, global collective action on climate change will continue to elude. 
CC This work is licensed under Creative DOI: 10.19080/OFOAJ.2017.05.555652
Your next submission with Juniper Publishers will reach you the below assets

- Quality Editorial service

- Swift Peer Review

- Reprints availability

- E-prints Servic

- Manuscript Podcast for convenient understanding

- Global attainment for your research

- Manuscript accessibility in different formats

( Pdf, E-pub, Full Text, Audio)

- Unceasing customer service

Track the below URL for one-step submission https://juniperpublishers.com/online-submission.php 